\title{
PENERAPAN MEDIA INTERAKTIF MATA PELAJARAN PEMELIHARAAN SISTEM ELECTRONIC FUEL INJECTION
}

\author{
Rustandi $^{1}$, Dedi Supriawan ${ }^{2}$, Tatang Permana ${ }^{3}$ \\ Universitas Pendidikan Indonesia \\ Jl. Dr. Setiabudhi No. 229 Bandung 40154 \\ aruztan44@gmail.com
}

\begin{abstract}
ABSTRAK
Penelitian ini bertujuan untuk mengetahui pengaruh penggunaan media interaktif yang berpengaruh pada hasil belajar siswa dan motivasi siswa setelah diterapkan pembelajaran dengan perangkatmedia interaktif. Penelitian ini menggunakan metode Penelitian Tindakan Kelas (PTK). Subjek dalam penelitian ini dilakukan dengan cara dilihat dari rata-rata nilai dikelas paa tahun sebelumnya dan didapat siswa kelas XI TKR 1 SMK Al Farisi Leles Garut tahun ajaran 2015/2016. Berdasarkan hasil penelitian yang telah dilakukan penelitian ini terdiri dari tiga siklus yaitu siklus awal, siklus I dan siklus II, yang mana persentasi mengenai motivasi dan hasil belajar adalah sebagai berikut, untuk motivasi belajar dari siklus awal sampai siklus II persentsinya yaitu siklus awal 47,5\%, siklus I 69,024\% dan siklus II 78,26\%. Sedangkan untuk hasil belajar prsentasinya yaitu siklus awal 10,33\%, siklus I 55,26\% dan siklus II 76,31. Penggunaan media interaktif dapat meningkatkan pemahaman siswa, maka sebaiknya untuk mata pelajaran yang sifatnya aplikatif digunakan media pembelajaran untuk membantu siswa dalam memahami materi materi yang diberikan guru. Media pembelajaran interaktif tentang ini terbukti dapat meningkatkan hasil belajar dan motivasi siswa yang signifikan.
\end{abstract}

Kata kunci: media interaktif, electronic fuel injection, hasil belajar

\section{PENDAHULUAN}

Sekolah Menengah Kejuruan (SMK) merupakan suatu lembaga pendidikan formal dimana lulusannya dipersiapkan untuk memasuki dunia kerja dan memiliki kemampuan yang sesuai dengan kebutuhan industri. Sekolah bukan saja mengharapkan siswa yang mampu, cakap, dan terampil, tetapi yang terpenting mereka mau giat belajar dan berkeinginan untuk mencapai hasil belajar yang optimal. Kemampuan, kecakapan, dan keterampilan tidak ada artinya jika mereka tidak mau bekerja keras dengan mempergunakan kemampuan, kecakapan, dan keterampilan yang dimilikinya. Sesuai dengan Standar Kompetensi pada Peraturan Menteri Pendidikan Nasional No. 23 Tahun 2006 menyatakan bahwa, satuan pendidikan SMK/MAK, tujuannya dicapai melalui muatan dan/atau kegiatan bahasa, matematika, ilmu pengetahuan alam, ilmu pengetahuan sosial, keterampilan, kejuruan, teknologi informasi dan komunikasi, serta muatan lokal yang relevan. SMK Al Farisi Leles Garut terdapat beberapa jurusan dalam menghadapi tantangan dunia kerja, salah satu jurusannya adalah Teknik

\footnotetext{
${ }^{1}$ Mahasiswa Departemen Pendidikan Teknik Mesin FPTK, UPI

${ }^{2}$ Dosen Departemen Pendidikan Teknik Mesin FPTK, UPI

${ }^{3}$ Dosen Departemen Pendidikan Teknik Mesin FPTK, UPI
} 
Kendaraan Ringan (TKR). TKR merupakan program keahlian di SMK Al Farisi Leles Garut yang akan mendidik siswanya agar mampu mengaplikasikan ilmunya didunia industri, karena selain dibekali dengan ilmu dasar di sekolah mereka juga dituntut untuk mampu menjadi siswa yang terampil dalam dunia usaha maupun industri. Tamatan SMK dibidang TKR harus memiliki sikap profesional yang siap kerja dan memiliki keahlian dibidang Teknik Kendaraan Ringan. Keahlian yang dimiliki lulusan SMK dibidang teknik kendaraan ringan ditunjukkan dengan nilai kompetensi yang diperolah pada saat masih mengikuti pembelajaran di sekolah (USID-Prestasi, 2013).

Hasil observasi awal mengenai hasil belajar siswa pada salah satu kompetensi dasar yaitu pemeliharaan electronic fuel injection system dikelas XI TKR 1 ditemukan beberapa temuan dalam proses pembelajaran pada kompetensi dasar, yaitu: proses pembelajaran masih berpusat pada guru, metode penyampaian materi didominasi dengan ceramah. Pada proses pembelajaran dengan metode ceramah siswa mayoritas pasif, hanya beberapa siswa saja yang berinteraksi dengan guru. Rendahnya keinginan dan keberanian serta kesempatan untuk berpartisipasi dalam kegiatan belajar mengajar. Sumber belajar utama yang digunakan siswa adalah catatan yang diberikan guru dalam kegiatan belajar mengajar. Penggunaan media pembelajaran masih kurang dan terbatas. Hasil belajar siswa sebagian besar tidak sampai pada Kriteria Ketuntasan Minimal (KKM), yaitu 75. Secara ideal siswa dikatakan tuntas pada mata pelajaran sistem EFI apabila sudah memenuhi nilai ketuntasan minimum (KKM) yaitu sebesar 75. Kenyataan dilapangan hasil belajar siswa pada kompetensi sistem EFI yang mana masih di bawah KKM. Hasil belajar siswa pada kompentsi sistem EFI yaitu: siswa yang tergolong tuntas hanya dua orang atau 5,40\% dan sisanya masih belum tuntas. Hasil belajar siswa pada kompetensi dasar sistem EFI disimpulkan masih sangat rendah.

Pembelajaran adalah suatu proses yang dilakukan oleh guru yang telah diprogram dalam rangka membelajarkan siswa untuk mencapai tujuan pembelajaran yang telah ditentukan sesuai dengan petunjuk kurikulum yang berlaku (Arsono, 2004). Guru dalam proses pembelajaran dituntut untuk menciptakan suasana belajar yang kondusif agar siswa dapat belajar secara aktif. Pengertian media belajar secara sederhana dapat diartikan sebagai media yang lebih dari satu media. Media belajar merupakan sistem yang mendukung penggunaan teks interaktif, audio, gambar diam, video dan grafik (Arsyad, 2007). Media belajar sebagai komunikasi yang menggunakan bermacam-macam kombinasi dari media yang berbeda, dapat 
menggunakan komputer atau tidak. Media belajar bisa mencakup teks, audio percakapan, musik, gambaran, animasi dan video. Media belajar adalah pemanfaatan komputer untuk membuat dan menggabungkan teks, grafik, audio, gambar bergerak (video dan animasi) dengan menggabungkan link dan tool yang memungkinkan pemakai melakukan navigasi, berinteraksi, berkreasi, dan berkomunikasi. Media belajar berfungsi sebagai informasi yang dipresentasikan dalam bentuk lebih dari satu bentuk semacam teks, suara, video, grafis, dan gambar (Daryanto, 2010). Pentingnya peranan motivasi dalam proses pembelajaran perlu dipahami oleh pendidik agar dapat melakukan berbagai bentuk tindakan atau bantuan kepada siswa. Motivasi dirumuskan sebagai dorongan, baik diakibatkan faktor dari dalam maupun luar siswa, untuk mencapai tujuan tertentu guna memenuhi/memuaskan suatu kebutuhan. Dalam konteks pembelajaran maka kebutuhan tersebut berhubungan dengan kebutuhan untuk pelajaran.

Hasil dari serangkaian kegiatan belajar mengajar adalah hasil belajar dengan objeknya siswa. Hasil belajar mempunyai peranan penting dalam pendidikan, bahkan menentukan kualitas belajar yang dicapai oleh siswa pada bidang studi yang dipelajari. Belajar mengajar pada dasarnya sebagai suatu proses yang akan mengakibatkan atau menimbulkan terjadinya suatu perubahan tingkah laku yang dapat diamati. Melalui tingkah laku yang teramati memungkinkan seseorang dapat mengetahui adanya suatu perubahan. Kompetensi adalah pernyataan terhadap apa yang harus dicapai seseorang untuk menunjukkan kemampuan pada ranah kognitif (pengetahuan), psikomotor (keterampilan), dan afektif (sikap).

Electronic fuel injection system itu sendiri merupakan salah satu kompetensi dari pelajaran produktif yang harus ditempuh peserta didik Teknik Kendaraan Ringan. Pelajaran produktif adalah kelompok pelajaran yang berfungsi membekali peserta didik agar memiliki kompetensi kerja sesuai Standar Kompetensi Kerja Nasional Indonesia (SKKNI). Berdasarkan penjelasan tersebut, pelajaran produktif adalah kelompok pelajaran di SMK yang berfungsi membekali siswa agar memiliki keahlian sesuai dengan kompetensi keahlian yang dipilihnya, serta sesuai dengan standar kerja Nasional. Di bawah ini kompetensi dasar electronic fuel injection system pada pelajaran produktif yang harus ditempuh peserta didik. Electronic control unit merupakan pusat dari sistem kontrol engine dan dibuat dengan teknologi micro electronic (Toyota, 2003). Unit ini mempunyai pengontrol digital oleh sebuah mikro komputer yang memungkinkan pembentukan proses informasi yang cepat dan sangat akurat. 


\section{METODE PENELITIAN}

Metode penelitian yang digunakan adalah penelitian tindakan kelas (classroom action research) kolaborasi. PTK merupakan salah satu upaya yang dapat dilakukan guru untuk meningkatkan kualitas peran dan tanggung jawab guru khususnya dalam pengelolaan pembelajaran. Penelitian tindakan kelas adalah suatu bentuk penelitian refleksif diri kolektif yang dilakukan oleh peserta dalam situasi sosial untuk meningkatkan penalaran dan keadilan praktik pendidikan dan praktik sosial mereka. Pemahaman terhadap praktik-praktik itu terhadap situasi tempat dilakukan praktik-praktik tersebut. Penelitian ini dilakukan dalam dua siklus.

\section{HASIL PENELITIAN}

Hasil penelitian diperoleh antara lain, ketuntasan hasil belajar dan peningkatan rata-rata kelas pada setiap siklus. Hasil penelitian secara keseluruhan dari awal sampai siklus II ditampilkan pada Tabel 1.

Tabel 1. Rata-rata kelas dan ketuntasan belajar

\begin{tabular}{clccc}
\hline No & \multicolumn{1}{c}{ ItemPenilaian } & Nilai Awal & Siklus I & Siklus II \\
\hline 1 & Nilai Siswa Terendah & 30 & 40 & 50 \\
2 & Nilai Siswa Tertinggi & 85 & 90 & 95 \\
3 & Rata-rata hasil belajar & 64,3 & 69,5 & 76,2 \\
4 & Peningkatan hasil belajar & $10,3 \%$ & $55,3 \%$ & $76,4 \%$ \\
\hline
\end{tabular}

Hasil penelitian yang berhubungan dengan hasil pembelajaran cenderung meningkat. Pada tes kemampuan awal rata-rata kelas adalah 64,3 dan prosentase ketuntasan 10,3\%, pada siklus I nilai rata-rata kelas adalah 69,5, dan ketuntasan belajar 55,3\%. Pada siklus II nilai rata-rata kelas meningkat menjadi $76,4 \%$, dan ketuntasan belajar juga meningkat menjadi 76,4\%. Hasil penelitian pada setiap siklus diperoleh peningkatan prestasi belajar dari rata-rata kelas kemampuan awal ke rata-rata siklus I sebesar 5,2. Peningkatan prestasi belajar dari ratarata kelas kemampuan awal ke rata-rata kelas siklus II sebesar 11,8. Sehingga pembelajaran dengan menggunakan media ineraktif dapat dikategorikan cukup efektif.

Hasil penelitian yang berhubungan dengan motivasi belajar siswa cenderung meningkat. Hasil penelitian terkait dengan motivasi siswa diperoleh da ditunjukkan pada Tabel 2. Pada tes awal nilai rata-rata kelas adalah 47,5 dan prosentase ketuntasan 47,5\%. Pada siklus I nilai rata- 
rata kelas adalah 69 dan ketuntasan belajar 69\%. Selanjutnya pada siklus II nilai rata-rata kelas meningkat menjadi 78,3 dan ketuntasan belajar juga meningkat menjadi 78,3\%.

Tabel 2. Hasil tes motivasi siswa

\begin{tabular}{rlccc}
\hline No & \multicolumn{1}{c}{ Item Penilaian } & NilaiAwal & Siklus I & SiklusII \\
\hline 1 & Nilai Siswa Terendah & 36,67 & 48,96 & 56,25 \\
2 & Nilai Siswa Tertinggi & 60,83 & 90,63 & 91,67 \\
3 & Rata-rata motivasi & 47,5 & 69, & 78,3 \\
4 & Peningkatan motivasi & $47,5 \%$ & $69 \%$ & $78,3 \%$ \\
\hline
\end{tabular}

Hasil penelitian pada setiap siklus diperoleh peningkatan prestasi belajar dari rata-rata kelas kemampuan awal nilai rata-rata siklus I sebesar 21,52. Peningkatan prestasi belajar dari rata-rata kelas kemampuan awal ke rata-rata kelas siklus II sebesar 9.24. Sehingga pembelajaran dengan menggunakan media interaktif dapat dikategorikan cukup efektif.

\section{PEMBAHASAN}

Hasil belajar siswa sangat dipengaruhi oleh proses pembelajaran yang berlangsung. Pembelajaran yang selama ini dilakukan untuk sistem EFI adalah menggunakan metode konvensional yaitu dengan ceramah serta bantuan papan tulis, spidol, penggaris dan lain-lain. Hasil penelitian awal dimana hasil belajar dan motivasi belajar siswa masih dibawah KKM, artinya pembelajaran yang digunakan belum maksimal. Ada beberapa cara dalam mengatasi permasalahan tersebut, diantaranya menerapkan beberapa alternatif baik dalam bentuk metode maupun lainnya. Media pembelajaran yang dapat meningkatkan hasil belajar dan motivasi belajar siswa khususnya pada kompetensi sistem EFI. Setelah melakukan observasi dan wawancara baik dari guru maupun siswa, mengambil alternatif dalam upaya meningkatkan hasil belajar siswa dengan menggunakan media interaktif (Sagala, 2008).

Hasil dan motivasi belajar siswa untuk setiap tahapan penelitian pada siklus awal masih menggunakan metode konvensional yaitu dengan ceramah serta bantuan papan tulis, spidol, penggaris dan lain-lain. Metode ceramah yang dianggap sebagai penyebab utama dari rendahnya hasil dan motivasi belajar siswa terhadap pelajaran memang patut dibenarkan. Anggapan itu sepenuhnya kurang tepat karena setiap metode atau model pembelajaran baik metode pembelajaran klasik termasuk metode ceramah maupun metode pembelajaran modern sama-sama mempunyai kelebihan dan kekurangan masing-masing, yang saling melengkapi satu sama lain. 
Hasil tes awal mengenai hasil belajar dan motivasi belajar masih di bawah KKM. Penelitian pada siklus I sudah menerapkan media interaktif dalam proses pembelajarannya. Media interaktif adalah alat perantara atau penghubung berkaitan dengan komputer yang bersifat saling melakukan aksi antar-hubungan dan saling aktif. Media interaktif adalah alat perantara yang dirancang dengan pemanfaatan komputer menggunakan unsur seperti suara (audio), gambar (visual) dan teks untuk menyampaikan suatu pesan (Sudjana dan Rivai, 2002). Hasil penelitian dapat dikatakan bahwa penggunaan media interaktif ada peningkatan untuk persentasi ketuntasan belajar siswa mengalami peningkatan 44,74\% dan motivasi belajar 21,52\%. Meskipun mengalami peningktan tetapi masih belum mencapai KKM sehingga harus dilanjut ke siklus II.

Hasil penelitian pada siklus II ini dilakukan atas dasar hasil refleksi pada siklus I. Pointpoint pada siklus I belum memenuhi KKM diperbaiki. Hasil penelitian diperoleh bahwa penggunaan media interaktif dinyatakan telah memenuhi KKM. Rata-rata penggunaan media pembelajaran meningkat dari 76,2 menjadi 78,3 dan peningkatan KKM dari 76,3\% menjadi $78 \%$, meskipun hanya sedikit peningkatanya dari nilai KKM yaitu 75\%, sehingga penelitian dihentikan sampai disiklus II.

\section{KESIMPULAN}

Kesimpulan bahwa penggunaan media interaktif pada mata pelajaraan memelihara sistem EFI memberikan dampak yang signifikan terhadap motivasi belajar siswa. Penggunaan media interaktif dalam pembelajaran dinyatakan berhasil. Pengaruh media interaktif terhadap hasil belajar siswa dapat diketahui dengan melakukan penelitian sebelum dan sesudah menggunakan media interaktif. Penggunaan media interaktif pada mata pelajaraan memelihara sistem EFI memberikan dampak yang signifikan terhadap hasil belajar siswa. Penggunaan media interaktif dalam pembelajaran dinyatakan berhasil.

\section{REFERENSI}

Arsyad, A. (2007). Media Pembelajaran. Jakarta: Raja Grafindo.

Arsono, dkk. (2004). Belajar dan Pembelajaran. Semarang: CV IKIP Semarang Press. Daryanto. (2010). Media Pembelajaran. Yogyakarta: Gava Media. 
Sujana, N. (2005). Penilaian Hasil Proses Hasil Mengajar. Bandung: PT Remaja Rosdakarya.

Sudjana, N. dan Rivai, A. (2002). Media Pengajaran. Bandung: Sinar Baru Algesindo.

Sagala, S. (2008). Konsep dan Makna Pembelajaran untuk Membantu Memecahkan Problematika Belajar dan Mengajar. Bandung: CV alfabeta.

Toyota, (2003). Team 21 Service Training. Jakarta: PT. Toyota Astra Motor.

USID-Prestasi. (2013). Kilas balik pendidikan Indonesia [forum online]. Diakses dari http://www.prestasi-iief.org/index.php/id/feature/68-kilas-balik-dunia-pendidikan-diIndonesia. 